\title{
Solid Waste Management: Its Sources, Collection, Transportation and Recycling
}

\author{
Gaurav K. Singh, Kunal Gupta, and Shashank Chaudhary
}

\begin{abstract}
Solid wastes may be defined as useless, unused, unwanted, or discarded material available in solid form. Semisolid food wastes and municipal sludge may also be included in municipal solid waste. The subject of solid wastes came to the national limelight after the passage of the solid waste disposal act of 1965 . Today, solid waste is accepted as a major problem of our society. In the United States over 180 million tons of municipal solid waste (MSW) was generated in 1988. At this generation quantity, the average resident of an urban community is responsible for more than $1.8 \mathrm{~kg}(4.0 \mathrm{lbs}$.) of solid waste per day. This quantity does not include industrial, mining, agricultural, and animal wastes generated in the country each year. If these quantities are added, the solid waste production rate reaches $45 \mathrm{~kg}$ per capita per day (100 lb. /c.d.). To introduce the reader to the solid waste management field, an overview of municipal solid waste problems, sources, collection, resource recovery, and disposal methods are presented in this paper. Greater emphasis has been given to the design and operation of municipal sanitary landfills, regulations governing land disposal, and leachate generation, containment and treatment methods.
\end{abstract}

Index Terms-Community, density, generation, landfills, population, solid waste.

\section{INTRODUCTION}

Municipal solid waste (MSW) includes wastes such as durable goods, nondurable goods, containers and packaging, food wastes yard wastes, and miscellaneous inorganic wastes from residential, commercial, institutional, and industrial sources. Example of waste from these categories include appliances, newspapers, clothing, food scarps, boxes, disposable tableware, office and classroom paper, wood pallets, and cafeteria wastes. MSW does not include wastes from sources such as municipal sludge, combustion ash, and industrial non-hazardous process wastes that might also be disposed of in municipal waste landfills or incinerators. Determining actual MSW generation rates is difficult. Different studies report a wide variation as they use different components. Many times industrial and demolition wastes are included in municipal solid wastes. Reference [1] has estimated that a total of over 180 million tons of MSW was generated in the United States in 1988, and that the generation is rising at a rate of slightly over 1 percent each year. This estimate is based on a material flow model utilized by [2], and is generally referred to as the EPA/Franklin model [1], [3]. Most of the increase in the MSW generation rate is

Manuscript received October 10, 2013; revised December 3, 2013.

The authors are with the Delhi Technological University in Department of Environmental Engineering, New Delhi-110042, India (e-mail: gauravkumardce@gmail.com, shshnkchaudhary73@gmail.com). due to population growth. However, each person is also generating more waste on an average. It is estimated that, without source reduction, MSW generation will increase to 200 million tons or $1.9 \mathrm{~kg} / \mathrm{c} . \mathrm{d}$ (4.2 lb. /c.d) by the year 1995 , and 216 million tons or $2.0 \mathrm{~kg} / \mathrm{c} . \mathrm{d}(4.4 \mathrm{lb}$. /c.d) by the year 2000. Based on current trends and information, EPA projects that 20 to 28 percent of MSW will be recovered annually by 1995. A successful solid waste management system utilizes many functional elements associated with generation, on-site storage, collection, transfer, transport, characterization and processing, resource recovery and final disposal [4]. All these elements are interrelated, and must be studied and evaluated carefully before any solid waste management system can be adapted. It is a multidisciplinary activity involving engineering principles, economics, and urban and regional planning.

\section{SOURCES AND CHARACTERISTICS}

Municipal solid waste (MSW) or urban solid waste is normally comprised of food wastes, rubbish, demolition and construction wastes, street sweepings, garden wastes, abandoned vehicles and appliances, and treatment plant residues. Quantity and composition of MSW vary greatly for different municipalities and time of the year. Factors influencing the characteristics of MSW are climate, social customs, per capita income, and degree of urbanization and industrialization. The composition of MSW as collected may vary greatly depending upon geographical region and season. The typical moisture content of MSW may vary from 15 to 40 percent depending upon the composition of the waste and the climatic conditions. The density of MSW depends upon the composition and degree of compaction. The uncompacted density of MSW is around " $150 \mathrm{~kg} / \mathrm{m}^{3}\left(250 \mathrm{lb} . / \mathrm{yd}^{3}\right)$." The density of collected solid waste is " $235-350 \mathrm{~kg} / \mathrm{m}^{3}$." The energy content of MSW as collected is " $9,890 \mathrm{~kJ} / \mathrm{kg}(4,260$ BTU/lb.)". Information of chemical composition of the organic portion of MSW is important for many processes such as incineration, composting, biodegradability, leachate generation, and others. The ultimate analysis of the organic fraction of MSW is in terms of the constituents carbon, hydrogen, oxygen, nitrogen, sulfur and ash.

\section{COLLECTION AND TRANSPORT}

Solid waste collection and transport involves storage at the generation and pick-up points, pick up by the crew, trucks driving around the neighborhood, and truck transport to a transfer station or disposal point. The collection is difficult, complex and costly. Collection of solid waste typically 
consumes $60-80$ percent of the total solid waste budget of a community. Therefore, any improvement in the collection system can reduce overall cost significantly [5].

\section{A. Onsite Storage and Handling}

In single family residential areas solid waste storage is handled by residents and tenants. Commonly used containers are plastic or galvanized metal containers, and disposable paper or plastic bags. The plastic or galvanized containers are 75-150 liter size with tight covering. The single use paper or plastic bags are generally used when curb service is provided and the homeowner is responsible for placing the bags along the curb. In high-rise buildings the waste is picked up by the building maintenance personnel, or special vertical chutes are provided to deliver the waste to a central location for storage, processing, or resource recovery. A recent development is to provide underground pneumatic transport systems to move waste to a central location for onsite storage, processing, or resource recovery. Apartment districts utilize stationary container systems into which the residents drop the solid wastes. Solid wastes from commercial buildings are collected in large containers that may be stationary or transportable.

\section{B. Collection of Solid Waste}

In residential areas, the most common collection methods are curb or alley, setout-setback, and backyard carry. In curb or alley service, the residents carry the single-use plastic bags and containers to the curb or collection point, and then return the empty container after pickup. Setout service utilizes a crew that carries the containers to the collection point. A separate collection crew empties the containers and residents return the empty containers. In setout-setback service, a third crew returns the empty containers. In backyard carry service, the collection crew transfers the solid waste into a wheeled barrel, and then unloads it into the collection truck. The containers remain in the backyard. Many communities have instituted regulations for separation of solid wastes at the source by residents. Components such as newspapers and cardboard, aluminum, mixed glass, and food wastes from restaurants have been separated at the source. Although the concept is good, the participation of the public drops quickly. Also, the price of recycle material fluctuates greatly, and it is often more expensive to recycle waste material. All these factors are considered for instituting a mandatory separation and recycling program. There is, however, much interest in recycling these days due to mounting pressures of decreasing landfill sites, environmental concerns, economic incentives, and political support. The usual vehicle for residential collection of solid wastes is the manually rear or side-loaded compaction truck operating with a crew of two or three, including the driver. The typical truck is 14 to $18 \mathrm{~m}^{3}$ (15 to 20 $\mathrm{yd}^{3}$ ), and can carry 4 to 5 tons of wastes to the disposal site or transfer station. Reference [6] reported features of new trucks that are equipped with an electronic control system for efficient operation and information storage and retrieval. Large self-loading compactor vehicles are equipped to centers, and then replace the empty ones for reuse at the site. Other container trucks provide container exchange service. They are equipped to carry an empty storage container to a collection point, pick up a full container and transport it to a central location or disposal site, then replace the empty container at a new location. The frequency of solid waste collection in most communities is once or twice per week. The daily truck routes are fixed and balanced to provide a fair day's work. Several methods are used to optimize the route. Reference [7] has developed heuristic routing rules.

\section{TRANSFER STATION AND TRANSFER}

If the disposal site is too far from the city, the time spent by the crew of the pickup truck in unproductive travel becomes excessive. As a result, it may be uneconomical to use collection trucks for travel to the disposal site. Transfer stations are therefore established at convenient locations, and one-person trailer or large trucks, 27 to $46 \mathrm{~m}^{3}$ (35 to $\left.60 \mathrm{yd}^{3}\right)$ or larger, are used to transfer wastes to the disposal site. Reference [8] reported that long-haul trailer units are more economical if average round-trip haul distance is more than $50 \mathrm{~km}$ (30 miles). Among the important considerations in planning and designing a transfer station are location, type of station, access, and environmental effects. At the transfer station, partial or complete solid waste processing such as sorting, shredding, compacting, baling, or composting may be provided. The objective is to reduce the volume, alter the physical form, and recover usable materials. It is important that the transfer station be located as near as possible to the generation center. Good access roads as well as secondary or supplemental means of transportation are necessary. Also, the site must be environmentally acceptable. If more than one transfer station and disposal sites are used, then optimum allocation of wastes from each transfer station to each disposal site will be necessary. This is a classical problem in the field of operations research. Several mathematical models can be used to achieve economical solid waste allocation to the transfer stations and distribution to the disposal sites. References [3], [9], [10] provided examples to optimize solid waste allocation and distribution.

\section{RESOURCE RECOVERY AND RECYCLING}

Many components of municipal solid wastes can be reused as secondary material. Among these are papers, cardboard, plastic, glass, ferrous metal, aluminum, and other nonferrous metals. These materials must be separated from MSW before they can be recycled. In this section, material recycling, and separation methods are first briefly presented, followed by bioconversion and refuse derived fuel (RDF) methods.

\section{A. Material Recycling}

The thrust of much state and local legislative action in mid-1980s was to encourage recycling of various components of municipal solid waste. Many have been made in the area of recycling, but not have been very successful. There are several reasons such as recycled material may contain increased levels of foreign materials that could interfere with product quality, uncertainty of supply and price variation of secondary material, methods of quality control of recycled material are not developed as for virgin materials. Many components of MSW are currently recycled. Among these are paper and paper products. These products are 
recycled in manufacturing building materials such as roofing felt, insulation and wallboard, and are also used to manufacture cartons and containers. Plastic is recycled to produce insulating material, sheets, bags, and structural material. Energy is recovered from combustion of organic wastes. Other components of MSW (1990) estimate that approximately $13 \%$ of MSW is currently recycled, and a 14 percent fraction is incinerated.

\section{B. Separation Methods}

The separation of material is performed by the users at the source, or separated from mixed refuse at a central processing facility. Material separation at the source involves users separating the material into different components, followed by transporting from the point of generation to a secondary material dealer. Unfortunately, active household response for separation at the source has been very poor. As a result, effort has been directed toward separation of MSW at a central facility. Handpicking is a long-used form of separation of a few components of solid wastes. In this operation, a conveyor moves the solid waste pass by a group of workers who pick up the designated components by hand. This method of separation is costly, and only a few bulky components, such as bundled newspapers and cardboard, can be separated. A mechanized material recovery method provided by [11] utilizes shearers that break open the bags and liberate cans and bottles. Trammel screens separate cans, glass and other inorganic material. The organic material is shredded and passed through air classifiers, which separate the components desired for recovery of fibers for paper making or for producing refuse derived fuel. Magnetic and electromechanical systems separate ferrous and nonferrous metals.

\section{Bioconversion}

Bioconversion of the organic fraction of municipal solid waste into a number of products including sugar, ethanol, and protein compost, has been reported in the literature by [4], [10]-[13].

\section{1) Sugar}

The recovery of fibers from paper has cellulose as major constituent. The cellulose is hydrolyzed into sugars. The hydrolysis of cellulose produces glucose and mixtures of other sugars. Hydrolysis of paper fibers is achieved under low $\mathrm{pH}$, or by enzymes. The hydrolysis reaction is given by Equation:

$$
\begin{aligned}
& \left(\mathrm{C}_{6} \mathrm{H}_{10} \mathrm{O}_{5}\right) n+n \mathrm{H}_{2} \mathrm{O} \underset{3447 \mathrm{kN} / \mathrm{m}^{2}(500 \mathrm{psi})}{\frac{\mathrm{H}_{2} \mathrm{SO}_{4}}{150-180^{0} \mathrm{C}}} \rightarrow n \mathrm{C}_{6} \mathrm{H}_{12} \mathrm{O}_{6} \\
& \text { or } \\
& \text { Enzyme }
\end{aligned}
$$

\section{2) Ethanol and other fermentation products}

Microorganisms can produce alcohols and short-chain organic acids. These products have commercial value in the industrial chemical market. Some of these fermentation reactions are given by equations

$$
\mathrm{C}_{6} \mathrm{H}_{12} \mathrm{O}_{6}+2 \mathrm{H}_{2} \mathrm{O} \longrightarrow 2 \mathrm{CH}_{3} \mathrm{CH}_{2} \mathrm{OH}+2 \mathrm{H}_{2} \mathrm{CO}_{3}
$$

$$
\begin{gathered}
2 \mathrm{CH}_{3} \mathrm{CH}_{2} \mathrm{OH}+2 \mathrm{H}_{2} \mathrm{O} \longrightarrow 2 \mathrm{CH}_{3} \mathrm{COOH}+4 \mathrm{H}_{2} \\
\mathrm{CH}_{3} \mathrm{COOH}+\mathrm{H}_{2} \mathrm{O} \longrightarrow \mathrm{CH}_{4}+\mathrm{H}_{2} \mathrm{CO}_{3} \\
4 \mathrm{H}_{2}+\mathrm{H}_{2} \mathrm{CO}_{3} \longrightarrow \mathrm{CH}_{4}+3 \mathrm{H}_{2} \mathrm{O}
\end{gathered}
$$

Many researchers have investigated the production of commercial quantities of these products using paper fibers recovered from municipal solid wastes. However, the cost of production and recovery of these products in a relatively pure state from MSW is much greater than the cost of producing the raw materials.

\section{3) Protein}

Earlier research conducted by the Denver Research Institute suggested that fibers produced from waste paper can be converted to protein using a fast-growing-hydrocarbon-cellulose digesting organism. The organism is Candia utilis culture, commonly called Torula yeast. The protein thus produced is usable by livestock [12]. Another concept, reported by [11], is to utilize processed organic wastes as the feedstock for a rapidly expanding population of red earthworms. This process is called annelidic recycling. The organic component is converted into a rich fertilizer in the form of worm of worm castings, the excess worms are dried into high-protein food supplement in animal food. Another similar concept is to breed flies and recover larvae as a protein source for animal feed supplement.

\section{INCINERATION AND ENERGY RECOVERY}

Incineration of MSW is practiced to reduce waste volume and recover energy. The batch-fed incinerators built in the 1930 s and 1940s reduced the volume but were major contributors of air pollution problems. Most of these incinerators have been shut down or replaced by newer designs. The newer incinerators utilize innovative technology to produce steam more efficiently and reduce air pollutants to greater extent. The capital and operating costs, however, are quite high. Reference [8] reported capital cost about $\$ 120$ million per 1000 tons of daily capacity, and operating cost of $\$ 15$ to $\$ 30$ per ton, for cities over 300,000 populations (1987 dollars). The unit cost of incinerators for smaller cities is even larger. The high cost of installing the air pollution control equipment forced municipalities to seek cheaper methods such as sanitary landfills for solid waste disposal. Due to stricter regulation on landfilling, and rapidly diminishing capacity, there is renewed interest in incinerator design and construction. Reference [9] reported that in 1978 there were only 56 facilities that remained active in United States. Today there are more than 100 facilities in operation, and over 100 more are in the planning and construction stages.

\section{REFUSE-DERIVED FUEL (RDF)}

Solid wastes may be burned directly in incinerators (a process called mass-burning) or converted to more efficient 
refuse-derived fuel (RDF). The solid waste is processed by means of size reduction and material separation techniques to obtain a product which has a substantial heat value. Physically, shredded and air classified organic fraction of solid wastes are burned along with a fossil fuel such as coal. Many boilers need only minor modifications to accept such fuel. Also, the shredded and air classified solid wastes can be made densely into cubes or pellets that are suitable for many thermal conversion processes such as incineration, gasification, and pyrolysis. Many communities have built refuse-to-energy plants that are fast replacing sanitary landfills. The steam is used for heating and for driving turbines to produce electricity. Reference [14] has reported that there are 190 municipal waste combustor plants in the USA. Of these, 142 facilities are waste-to-energy combustors. The total processing capacity exceeds 31.4 million tons of MSW per year. These facilities do not include RDF-processing plants or simple incinerators. There are also approximately 49 waste-to-energy combustors planned or under construction.

\section{DISPOSAL BY LANDFILLING}

The volume of municipal solid waste is greatly reduced by incineration, conversion processes or resource recovery. In all cases, there is a residue that must be disposed of so that it no longer creates a nuisance or hazard to the society. Engineering principles must be followed for site selection and design of ultimate-land disposal methods. An acceptable land disposal method of MSW and residues utilizes sanitary landfills. Sanitary landfilling is the most common method of solid waste disposal in the United States. It is economical, and applies to all components of MSW. Proper site selection is perhaps the most difficult part of disposal by landfilling. The operation involves compaction of solid wastes in layers, then covering with a layer of compacted soil at the end of each day's operation. In recent years, special care has been required in site selection, refuse compaction, cover application, leachate collection and treatment, and site monitoring.

\section{CONCLUSIONS}

The quantity of MSW generated is increasing rapidly due to increasing population and change in lifestyle. The current MSW crisis should be approached holistically; while planning for long term solutions, focus on the solving the present problems should be maintained. The Government and local authorities should work with their partners to promote source separation, achieve higher percentages of recycling and produce high quality compost from organics. While this is being achieved and recycling is increased, provisions should be made to handle the non-recyclable wastes that are being generated and will continue to be generated in the future. Policy to include waste-pickers in the private sector must be introduced to utilize their low cost public and environmental service and to provide better working conditions to these marginalized populations.

\section{REFERENCES}

[1] U.S. Environmental Protection Agency, "Characterization of municipal solid waste in the United States," Solid Waste and Emergency Response, Washington D.C., 1990.

[2] U.S. Environmental Protection Agency, "Characterization of municipal solid waste in the United States," Final Report Prepared by Franklin Associates, Inc, 1988.

[3] P. A. Vesilind, J. J. Pierce, and R. F. Weiner, Environmental Engineering, 2nd ed. Boston, MA: Butterworth's, 1988.

[4] U.S. Environmental Protection Agency, "Decision-Makers guide in solid waste management," SW-500, Washington D.C.: U.S. Government Printing Office, 1976.

[5] U.S. Congress, "Facing America's trash: What next for municipal solid waste," OTA-0-424, Office of Technology Assessment, Washington D.C.: U.S. Government Printing Office, 1989.

[6] R. Woods, "Refuse vehicles of the '90s," Waste Age, vol. 23, no. 5, 38-44, 1992.

[7] K. A. Shuster and D. A. Schur, "Heuristic routing for solid waste collection vehicles," SW-11, U.S. Environmental Protection Agency, 1974.

[8] Matrecon, "Lining of waste impoundment and disposal facilities," SW-870, U.S. Environmental Protection Agency, Cincinnati, OH, 1980.

[9] M. L. Davis and D. A. Cornwell, Introduction to Environmental Engineering, 2nd ed. New York: MacGraw-Hills, Inc, 1991.

[10] G. Tchobanoglous, H. Theisen, and S. Vigil, "Integrated solid waste management," Engineering Principles and Management Issues, New York: McGraw Hill, 1993.

[11] D. C. Wilson, Waste Management: Planning, Evaluation Technologies, Oxford: Clarendon Press, 1981

[12] N. L. Drobny, H. E. Hull, and R. F. Testin, "Recovery and utilization of municipal solid waste," EPA-SW-10C-71, U.S. Environmental Protection Agency, Office of Solid Waste Management Program, Washington D.C. (NTIS No. PB-204 922), 1971.

[13] P. A. Vesilind and A. E. Rimer, Unit Operations in Response Recovery Engineering, Englewood Cliffs, NJ: Prentice Hall, Inc, 1981.

[14] J. V. L. Kiser, "Municipal waste combustion in North America," Waste Age, vol. 23, no. 11, pp. 26-34, 1992.

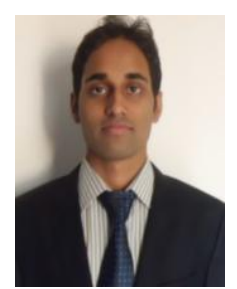

Gaurav Kumar Singh was born in Darbhanga, Bihar, India on March 17, 1993. He passed his 10th class in 2008 and 12th class in 2010 from The Air Force School (TAFS), Delhi, India achieving 1st division with distinction. He is currently pursuing B.Tech. in environmental engineering from Delhi Technological University, Delhi, India and expected year of completion of course is 2015.

He did internship in Central Road Research Institute (CRRI) on the project of measuring the fuel consumption of vehicles at idling condition and in Delhi Metro Rail Corporation (DMRC) on energy efficiency of metro trains. He published research paper on "Spectrometric determination of $\mathrm{NO}_{2}$ in ambient air and its control" in International Journal of Environmental Engineering and Management (IJEEM) and presented at the 2nd International Conference on "Agriculture, Food Technologies and Environment (AFTENA 2013)" held in JNU, India.

Mr. Singh was awarded scholarship of Rs. 5,000 by AFFWA (IAF) for obtaining above $80 \%$ in AISSCE and qualified prestigious All Indian Engineering Entrance Examination and stood among top $0.90 \%$ students that appeared for AIEEE 2011. Mr. Singh has also achieved expertise in AutoCAD 2D \& 3D and was presented 'Grade A' in prestigious United Nation Rio+20 India Program.

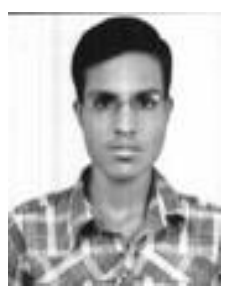

Kunal Gupta was born in Ajmer, Rajasthan, India on March 30, 1993. He passed his AISSE exam in 2009 and AISSCE exam in 2011 from Aklank Public School, Kota, Rajasthan, India achieving 1st division with distinction. $\mathrm{He}$ is currently pursuing B.Tech. in environmental engineering from Delhi Technological University, Delhi, India and expected year of completion of course is 2015 .

He did internship in DCM Shriram Consolidated Ltd. (DSCL), Kota, Rajasthan, India on the project of air quality monitoring in heavy industrial areas and in Kota Thermal power Station. He published 
research paper on "Spectrometric determination of $\mathrm{NO}_{2}$ in ambient air and its control" in in International Journal of Environmental Engineering and Management (IJEEM) and presented in the 2nd International Conference on "Agriculture, Food Technologies and Environment (AFTENA 2013)" held in JNU, India.

Mr. Gupta had qualified prestigious All Indian Engineering Entrance Examination and stood among top $0.92 \%$ students that appeared for AIEEE 2011.

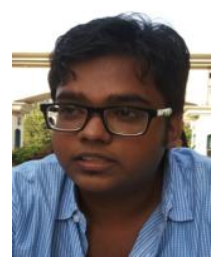

Shashank Chaudhary was born in Lucknow, Uttar Pradesh, India on May 20, 1991. He passed his AISSE exam in 2008 and AISSCE exam in 2010 from Delhi Public School, Lucknow, Uttar Pradesh, India achieving 1st division with distinction. He is currently pursuing B.Tech. in Polymer Science and Chemical Technology from Delhi Technological University, Delhi, India and expected year of completion of course
He did his internship in BASF-The Chemical Company, Delhi, India as a mentor in Indo-German Urban Mela Delhi, India and Hindustan Petroleum Corporation Limited Lucknow, India. He worked as a corporate team member of team DTU-Solaris (India's one and only Solar Car Team).

Mr. Chaudhary had qualified prestigious All Indian Engineering Entrance Examination and stood among top $0.92 \%$ students that appeared for AIEEE 2011.

is 2015 . 